higher than those recommended by Oakley et al.

How then should we proceed? I would like to propose that carrier protein be always added to low-dose continuous infusions of insulin. This can be in the form of human albumin or plasma protein at the concentration of not less than $2 \mathrm{~g} / \mathrm{l}$. When suitable preparations are not immediately available use can be made of the patient's own plasma proteins. A simple effective way of preparing a suitable solution is to take $5 \mathrm{ml}$ of the patient's blood into a $50-\mathrm{ml}$ syringe, make up the desired volume with physiological saline, and then add the required amount of insulin and mix well. When the syringe is placed in the syringe-pump the red cells sediment at the bottom and the resulting solution has approximately $4 \mathrm{mg} / \mathrm{ml}$ carrier protein which will be in stable solution for as long as 24 hours if necessary. It seems to me that this technique is so simple and safe that it can always be used when convenient preparations of carrier proteins are not at hand.

\section{PETER SöNkSEN}

Department of Medicine,
St Thomas's Hospital Medical School,

London SE1

Sönksen, $\mathrm{P} H$, et al, Clinical Science and Molecular Medicine, 1973, 45, 633.

Sönksen, P H, et al, Lancet, 1972, 2, 155.

Sönksen, P H, et al, Diabetologia, 1965, 1, 208.

Oakley, W G, Pyke, D A, and Taylor, K W,
Diabetes and its Management, 2nd edn, p 112.
Oxford, Blackwell Scientific, 1975.

SIR,-Dr E W Kraegen and others (23 August, p 464) state that when dilute solutions of insulin are prepared for intravenous infusion significant losses of the order of $60-80 \%$ will occur as a result of adsorption of insulin to glass or plastic surfaces.

In order to check this statement we made up insulin solutions in physiological saline containing $40 \mathrm{U} / 1$ and left these in contact with both clean glass and polyethylene surfaces for two hours with intermittent shaking. Immediately afterwards the solutions were assayed against the 4th International Insulin Standard using the official method of the British Pharmacopoeianamely, mouse convulsion assay. We have not been able to detect a significant loss of insulin from any of these solutions.

The low recoveries reported by $\mathrm{Dr}$ Kraegen and his colleagues may have been due to their use of a radioimmunoassay technique for assaying insulin in solutions that had been frozen at $-20^{\circ} \mathrm{C}$ and then subsequently thawed. It has been our experience that this always leads to low recoveries of insulin, probably as a result of disruption of the insulin-antibody binding sites.

Research Biological Support,

M BURTON

Company Ltd,

Nottingham

\section{Laboratory diagnosis of malaria}

SIR,-Diagnosis of malaria is made in the laboratory by the use of stained thick and thin blood films, which should be made immediately the patient is bled. Microscopical examination of blood films made from blood previously collected into anticoagulants can produce difficulties in identification of malaria parasites.

We performed a simple experiment by taking blood from two patients (one with Plasmodium vivax malaria, one with $P$ malariae infection). Immediate thin films were made and the rest of the blood was put into containers with either heparin, sodium oxalate, or EDTA as anticoagulant. The containers were left on the bench at room temperature and thin films made at varying intervals up to 48 hours later. The slides were stained together and examined blind by one of us (PGS). Within 30 minutes of being in heparin or sodium oxalate distortion of parasites had occurred; this worsened with the passage of time, rendering species diagnosis, and occasionally even a diagnosi of malaria, difficult if not impossible. Some distortion occurred with EDTA but was not so marked as with heparin or sodium oxalate, especially within about four hours of bleeding

As a rule malaria should be diagnosed on blood films made at the patient's bedside. If this is not possible blood should be drawn by venepuncture, placed in an EDTA container, and films made preferably within the hour and certainly not more than three hour later.

Hospital for Tropical Diseases,

G H REE

London NW1

P G SARGEAUN

\section{Dependence on antiparkinsonian drugs}

SIR,-I wish to add to $\operatorname{Dr} M$ E Shariatmadari's case report of orphenadrine dependence (23 August, p 486). A drug monitoring programme begun in 1973 at ou Modecate (fluphenazine) clinic revealed similar problems of drug dependency with benzhexol (trihexyphenidyl hydrochloride) This was apparent in our younger schizophrenics who were on the fringe of the drug scene. The effects described included elation or "highs" and the drug was used for "tripping on," relieving depression swapping for other illicit drugs, or mixing with alcohol or Mandrax. We observed several patients after taking excessive amounts present with an acute brain syndrome. Frequently this group demanded more tablets from the clinic, the pharmacy, the duty doctor, or other hospitals. Their resistance to reduction or cessation of antiparkinsonian drugs $s^{1}$ played a part in the high proportion of our patients $(57.5 \%)$ receiving these drugs in 1973. Feeding back to the hospital staff of this problem and a greate use of benztropine has reduced our antiparkinsonian medication to $30.3 \%$ in a large sample of 379 outpatients.

Both orphenadrine and benzhexol have hepatic enzyme-inducing properties. Other non-therapeutic drug interactions include a potentiating and worsening of tardive dyskinesia. ${ }^{2}$ With over 400000 patients on depot neuroleptics world wide, the clinician should avoid adding to the problems of the schizophrenic.

Royal Park Psychiatric Hospital,

PETER MARRIOT

Parkville,

Victoria, Australia

1 Marriott, P, Grigor, J, and Hiep, A, British Fournal of Psychiatry, 1975, 126, 204.
Marriott, P, Medical fournal of Australia, 1975,
2, 33.

\section{How much can ancillaries take over?}

SIR,-May I comment on the statement, "Of course, throughout much of Europe and the USA nurses give most of the anaesthetics. So why have a specialty of anaesthesia at all?" which is attributed to your good self as chairman of the conference on medical manpower held at Canterbury last November (3 January, p 29)? I hope that this was merely a provocatively inaccurate remark from the chair calculated to stimulate discussion. I cannot believe that anyone in your position could possibly fail to distinguish between the skill of administering anaesthesia and the responsibilities of the modern specialty of anaesthesia.

It is true that nurses do administer anaesthesia in other countries, but they are increasingly, and in some countries exclusively, under the guidance of physician anaesthetists. The medical members of the modern specialty of anaesthesia organise and carry out many more tasks within the hospital service besides their original raison d'être of administering anaesthesia, including emergency aid and resuscitation, preand postoperative care, intensive therapy, and pain control.

It must be obvious that the principle of having "six nurse-anaesthetists supervised by one consultant anaesthetist," as $\mathrm{Mr}$ F S A Doran suggests in the same report, would be impracticable in most hospitals in the United Kingdom because of the peculiar British architectural custom of distributing individual operating theatres in isolated sites all over the hospital complex. Whatever future attitudes to the possible use of the nurse-anaesthetist in the UK may be, however, I trust that you will acknowledge that she would in no way be a substitute for the modern physician-anaesthetist with his many executive responsibilities within the hospital

T B Boulton Editor, Anaesthesia

Association of Anaesthetists of Great Britain and Ireland,

London WC1

${ }_{*}^{*}$ Dr Boulton can rest assured that the remark to which he refers was indeed made in a light-hearted spirit with the sole purpose of stimulating discussion.-ED, BMF.

\section{SLE precipitated by antibiotics in Sjögren's syndrome}

SIR,-The claim by Dr D M Grennan and his colleagues (15 November, p 385) of "multi-system features of systemic lupus erythematosus (SLE)" developing on two separate occasions in a patient with Sjögren's syndrome after antibiotics and their conclusions on the relationship of Sjögren's syndrome to SLE do not meet current diagnostic criteria.

On the first admission SLE was diagnosed from LE cells in the patient's blood film, worsening poly arthritis, pericarditis, and a "borderline abnormal" DNA binding of $28 \%$. However, LE cells may be found in uncomplicated rheumatoid arthritis and more commonly in Siögren's syndrome. ${ }^{1}$ and after anti-inflammatory drugs. ${ }^{2}$ Pericarditis can be complication of rheumatoid arthritis $(10 \%$ of inpatients with rheumatoid disease ${ }^{3}$ ). DNA binding values of over $30 \%$ have been recorded in some cases of Sjögren's syndrome unassociated with SLE $;^{4}$ thus on this occasion the patient had only 